\title{
Pathophysiology of elevated ascites fluid cholesterol in malignant ascites
}

\section{Increased ascites to serum relation of proteins and lipoproteins in patients with peritoneal carcinomatosis as compared to patients with cirrhosis of the liver}

\author{
Dieter Jüngst, Yining Xie and Alexander L. Gerbes \\ Department of Medicine II, Klinikum Grosshadern, Ludwig-Maximilians-University of Munich, Munich, Federal Republic of Germany
}

(Received 17 November 1990)

\begin{abstract}
The existence of marked elevations of ascitic fluid cholesterol has been observed in patients with peritoneal carcinomatosis compared to patients with cirrhosis and has been found useful in differential diagnosis. This finding could be caused by an enhanced movement of plasma lipoproteins into the peritoneal cavity. To test this hypothesis we deturmined the fasting concentrations of total, high density lipoprotein (HDL)- and low density lipoprotein (LDL)-cholesterol, apolipoprotein$A_{1}\left(a p o-A_{1}\right)$ and apolipoprotein-B (apo-B) in serum and ascites of 17 patients with cirrhosis and 16 patients with peritoneal carcinomatosis. The movement of proteins from plasma to ascites was calculated from the ascites/serum concentration ratios of six different sized proteins with a molecular mass ranging from $54 \mathrm{kDa}$ to $971 \mathrm{kDa}$. Mean values (mg/dl) for total cholesterol (92.6 vs. 21.0), HDL-cholesterol (15.6 vs. 1.8), LDL-cholesterol (63.4 vs. 16.1$)$, apo- $A_{1}(50.2$ vs. 13.6) and apo-B (41.2 vs. 12.9) in ascites were significantly higher in peritoneal carcinomatosis than in cirrhosis. These differences could only partially be explained by the higher serum concentrations of these parameters in peritoneal carcinomatosis, but were mainly due to a lower selectivity for the movement of plasma proteins and lipoproteins into ascites (mean ascites/serum (A/S) ratio: $0.30-0.77$ ) in periioneal carcinomatosis as compared to cirrhosis (mean ascites/serum ratio: $0.11-0.21$ ). In both groups about $85 \%$ of the total cholesterol in serum and ascites consisted of HDL- and LDL-cholesterol. These findings support the hypothesis that elevations in ascitic cholesterol in peritoneal carcinomatosis compared to cirrhosis are mainly caused by the increased movement of plasma HDL and LDL into the peritoneal cavity.
\end{abstract}

High total lipid concentrations have been reported in the ascites of patients with malignant neoplasms compared to patients with non-malignant ascites (1). In an additional study, markedly elevated concentrations of total cholesterol were found in malignant and inflammatory ascitic fluid compared to ascites from patients with cirrhosis (2). Recently these findings have been confirmed and the clinical value of ascitic cholesterol to differentiate between cirrhotic and malignant ascites has been established (3-7). The pathogenesis of high ascitic cholesterol levels in patients with malignant disease is not fully understood. It has been suggested that a minor fraction of the cholesterol in malignant ascites might be derived from cell membranes and thus contribute to elevated ascitic concentrations in these patients (8). Since low density lipo- proteins have been isolated from ascitic fluid $(8,9)$, the marked elevations of ascitic cholesterol observed in patients with peritoneal carcinomatosis compared to patients with cirrhosis could be caused by an enhanced movement of plasma lipoproteins into the peritoneal cavity. To test this hypothesis, we compared the ascites to the serum relation of proteins and lipoproteins in patients with cirrhosis or peritoneal carcinomatosis.

\section{Materials and Methods}

\section{Patients}

A total of 33 patients with ascites were investigated (mean age: 57 ; range: $15-81$ ). The group with chronic 
liver disease ( 13 males and four females) included 10 patierts with alcoholic and seven patients with posthepatitic cirrhosis. Since no differences of ascitic proteins ard lipoproteins between the two subgroups were observed they were considered one group for statistical evaluation. Sixteen patients suffered from peritoneal carcinomatosis (five males and 11 females): six with ovarian carcinoma, two with breast cancer, two with adenocarcinoma of the stomach and one each with leukemia, lymphoma, hepatocellular carcinoma, carcinoma of bladder, carcinoma of kidney and adenocarcinoma of unknown origins. Diagnosis in all patients with cirrhosis was confirmed by biopsy, and hepatic malignancy was excluded by ultrasound or computed tomography. Twelve patients with peritoneal carcinomatosis had a positive ascitic cytology, and in four, the definitive diagnosis was made at autopsy.

None of the patients with peritoneal carcinomatosis had laboratory or ultrasound evidence of liver metastasis.

The length of the history of ascites in our patients varied from a few weeks to 2 years. Usually ascites in patients with peritoneal carcinomatosis had been diagnosed only 2-6 weeks prior to admission to the hospital. Patients with long-standing ascites mostly had liver disease due to the more favorable prognosis. The amount of ascitic fluid was classified by ultrasound and clinical examination. Of 17 patients with cirrhosis seven revealed moderate and 10 tense ascites, and of 16 patients with peritoneal carcinomatosis ascites was moderate in nine and tense in seven cases. Fifteen of the 17 ascitic patients with cirrhosis and 11 of the 16 patients with peritoneal carcinomatosis received diuretic treatment at ine time of the study.

\section{Collection of specimens}

In each patient, samples of blood and ascites were collected simultaneously after an overnight fast and centrifuged at $3000 \mathrm{rpm}$ for $10 \mathrm{~min}$. The supernatants were stored in $1.0 \mathrm{ml}$ aliquots at $-70^{\circ} \mathrm{C}$ until analysis.

\section{Lipid assays}

Total cholesterol determination was performed enzymatically with a commercial test kit (Boehringer, Mannheim, F.R.G.) (10). HDL-chulesterol was determined after precipitation of LDL and very low density lipoprotein (VLDL) with phosphotungstate and $\mathrm{Mg}^{2+}(11)$ and LDLcholesterol was measured after precipitation with polyvinyl sulfate (12).

\section{Protein analysis}

Total protein was measured by a commercial biuret method (Merck, Darmstadt, F.R.G.) (13). The concentrations of six proteins with different molecular masses, $\alpha_{1}$-antitrypsin (54 kDa), albumin (66 kDa), transferrin
(76 kDa), IgG (150 kDa), $\alpha_{2}$-macroglobulin (725 kDa) and $\operatorname{IgM}(971 \mathrm{kDa})$ were determined by laser nephelometry using specific antisera (Behring, Marburg, F.R.G.) (14). In addition, apo- $A_{1}$ and apo-B were measured by laser nephelometry as marker proteins for $H D L$ and LDL, respectively (15).

\section{Statistical evaluation}

The results were analysed separately for the group with cirrhosis (17 patients) and the group with peritoneal carcinomatosis (16 patients).

In every patient an ascites/serum concentration ratio (A/S) was calculated for each of the six proteins. In both groups, the mean A/S ratio for each protein was plotted against the logarithm of its molecular weight according to Henderson et al. (16). Then two regression lines were computed by the method of least squares.

Using mean and standard error of the mean (S.E.), statistical analysis of the data was performed by applying the Student unpaired $t$-test and the Spearman correlation coefficient. A $p$ value below 0.05 was considered significant.

Results

Table 1 summarizes the concentrations in serum and ascites of total cholesterol, HDL-cholesterol, LDL-cholesterol, apo-A and apo-B, in both groups of patients. Pa-

\section{TABLE 1}

Concentrations of total, HDL-, LDL-cholesterol, apo- $\mathrm{A}_{1}$, apo-B (mean \pm S.E.) and percentage of HDL- and LDL-cholesterol of total cholesterol in serum and ascites of 17 patients with cirrhosis and 16 patients with peritoneal carcinomatosis

\begin{tabular}{llrc}
\hline & & Cirrhosis & $\begin{array}{c}\text { Peritoneal } \\
\text { carcinomatosis }\end{array}$ \\
\hline $\begin{array}{l}\text { Total cholesterol } \\
\text { (mg/dl) }\end{array}$ & $\begin{array}{l}\text { serum } \\
\text { ascites }\end{array}$ & $\begin{array}{r}92.0 \pm 9.2 \\
21.0 \pm 4.3\end{array}$ & $\begin{array}{c}157.0 \pm 7.9 \\
92.6 \pm 6.8\end{array}$ \\
$\begin{array}{l}\text { HDL-cholesterol } \\
\text { (mg/dl) }\end{array}$ & serum & $20.8 \pm 3.6$ & $36.5 \pm 2.1$ \\
& ascites & $1.8 \pm 0.4$ & $15.6 \pm 1.3$ \\
$\begin{array}{l}\text { LDL-cholesterol } \\
\text { (mg/dl) }\end{array}$ & serum & $59.0 \pm 6.7$ & $94.5 \pm 6.2$ \\
& ascites & $16.1 \pm 3.5$ & $63.4 \pm 5.7$ \\
$\begin{array}{l}\text { Apolipoprotein A, } \\
\text { (mg/dl) }\end{array}$ & serum & $55.0 \pm 7.5$ & $100.9 \pm 3.7$ \\
& ascites & $13.6 \pm 2.8$ & $50.2 \pm 2.4$ \\
$\begin{array}{l}\text { Apolipoprotein B } \\
\text { (mg/dl) }\end{array}$ & serum & $58.8 \pm 6.2$ & $114.0 \pm 6.1$ \\
& ascites & $12.9 \pm 2.5$ & $41.2 \pm 2.3$ \\
HDL-and LDL- & & & \\
cholesterol/total & & & \\
$\begin{array}{l}\text { cholesterol } \\
\text { (\%) }\end{array}$ & serum & $85.0 \pm 2.0$ & $84.0 \pm 4.0$ \\
\hline
\end{tabular}


tients with peritoneal carcinomatosis revealed 1.6 -fold higher $(p<0.001)$ total serum cholesterol values compared to the subjects with cirrhosis. A similar ratio was observed concerning the concentrations of serum HDLand LDL-cholesterol as well as apo-A and apo-B. Ascites concentrations of these parameters differed more markedly with 4.0 -fold higher values $(p<0.001)$ in peritoneal carcinomatosis than in cirrhosis. In both groups about $85 \%$ of the total cholesterol in serum and ascites consisted of HDL- and LDL-cholesterol (Table 1).

Total protein content and the concentrations of six proteins with different molecular weights determined in serum and ascites are displayed in Table 2. Ascites/serum ratios of these proteins were plotted against the logarithm of their corresponding molecular weight (Fig. 1).

A significant negative correlation between ascites/serum ratios and the mean of the molecular weight of the various proteins was obtained in both groups of patients.

The mean A/S ratios of the six proteins were about 3times higher in the patients with peritoneal carcinomatosis (mean A/S ratios: $0.38-0.77$ ) than in the group with cirrhosis (mean A/S ratios: $0.12-0.2$ ). In the total of 33 patients, a close correlation of HDL-cholesterol and apo$\mathrm{A}_{1}(r=0.89, p<0.001)$ and $\mathrm{LDL}$-cholesterol and apo-B $(r=0.86, p<0.0001)$ in ascites was found. The correlation between HDL-cholesterol and apo- $\mathrm{A}_{1}$ in cirrhotic ascites $(r=0.90, p<0.0001)$ was higher in comparison with malignant ascites $(r=0.59, p<0.02)$. LDL-cholesterol and apo-B levels correlated similar in cirrhotic ascites $(r=0.69, p<0.005)$ and malignant ascites $(r=0.60, p<$ 0.02). For each group the mean $A / S$ ratio of apo- $A_{1}$ and HDL-cholesterol was plotted against the $\log M_{\mathrm{r}}$ of HDL and the mean A/S ratio of apo-B and LDL-cholesterol

\section{TABLE 2}

Concentrations of total protein and six different proteins in serum and ascites (mean \pm S.E.) of 17 patients with liver cirrhosis and 16 patients with peritoneal carcinomatosis

\begin{tabular}{cccc}
\hline & & Cirrhosis & $\begin{array}{l}\text { Peritoneal } \\
\text { carcinomatosis }\end{array}$ \\
\hline $\begin{array}{l}\text { Total protein } \\
\text { (g/dl) }\end{array}$ & serum & $6.4 \pm 0.3$ & $6.4 \pm 0.2$ \\
& ascites & $1.6 \pm 0.3$ & $4.2 \pm 0.2$ \\
$\begin{array}{l}a_{1} \text {-Antitrypsin } \\
\text { (mg/dl) } 54 \mathrm{kDa}\end{array}$ & serum & $290 \pm 19$ & $467 \pm 35$ \\
& ascites & $92 \pm 18$ & $340 \pm 29$ \\
Albumin & serum & $2648 \pm 111$ & $2997 \pm 163$ \\
(mg/dl) $66 \mathrm{kDa}$ & ascites & $738 \pm 129$ & $2287 \pm 145$ \\
& & & \\
Transferrin & serum & $179 \pm 16$ & $205 \pm 8$ \\
(mg/dl) $76 \mathrm{kDa}$ & ascites & $53 \pm 14$ & $146 \pm 10$ \\
& & $1857 \pm 232$ & $1184 \pm 127$ \\
IgG & serum & $403 \pm 71$ & $778 \pm 83$ \\
(mg/dl) $150 \mathrm{kDa}$ & ascites & & \\
& & $146 \pm 6$ & $140 \pm 11$ \\
$\alpha_{2}$-Macroglobulin & serum & $24 \pm 3$ & $56 \pm 5$ \\
(mg/dl) $725 \mathrm{kDa}$ & ascites & & \\
IgM & serum & $237 \pm 32$ & $98 \pm 10$ \\
(mg/dl) $971 \mathrm{kDa}$ & ascites & $36 \pm 6$ & $44 \pm 5$ \\
\hline
\end{tabular}

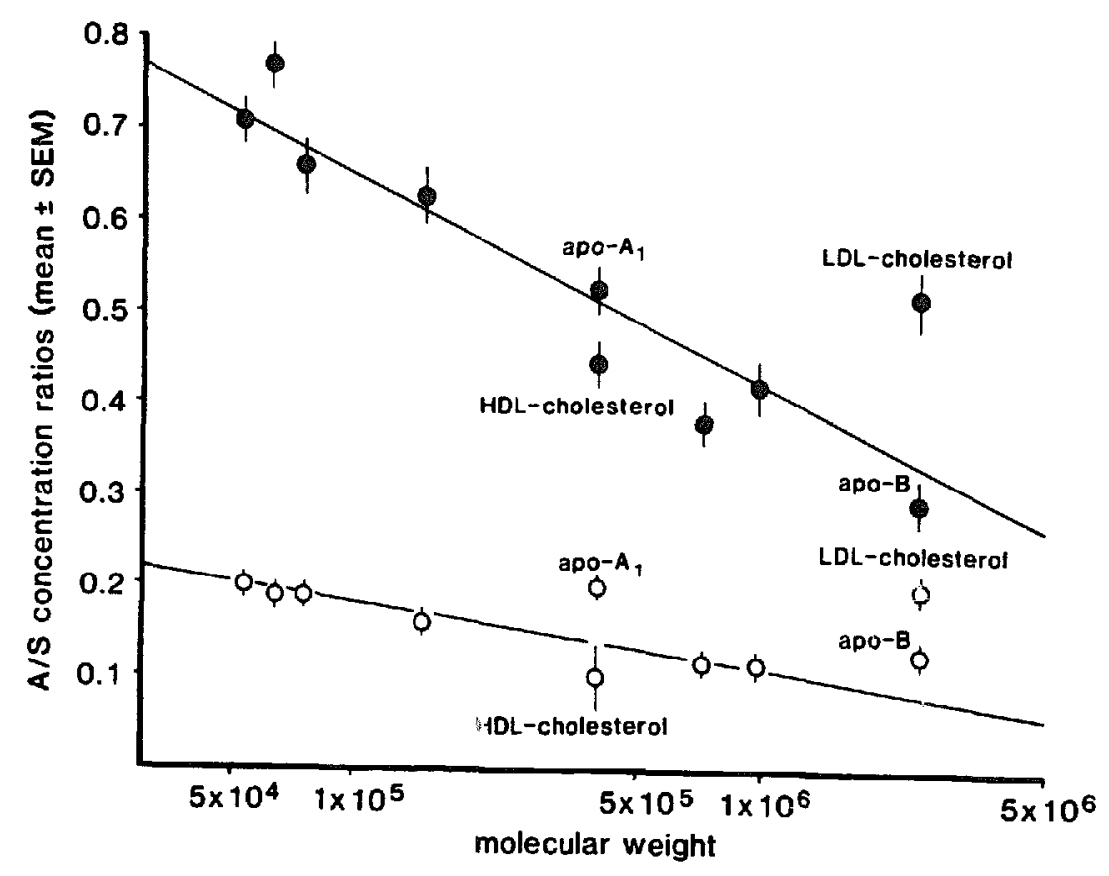

Fig. 1. Regression equation of $\log M_{\mathrm{r}}$ against the ascites/serum (A/S) ratio (mean \pm S.E.) of six proteins ( $\alpha_{1}$-antitrypsin, albumin, transferrin, IgG, $\alpha_{2}$-macroglobulin, IgM) in 17 patients with liver cirrhosis $(O)(r=0.99, p<0.0001)$ and of 16 patients with peritoneal carcinomatosis (O) $(r=0.96, p<0.02)$. Mean $\pm S$.E. AVS ratios of apo- $A_{1}$ and HDL-cholesterol were ploted according to the $\log M_{r}$ of HDL, and mean $\pm S$.E. $\mathrm{A} / \mathrm{S}$ ratios of apo-B and $\mathrm{LDL}$-cholesterol were plotted in relation to the $\log M_{\mathrm{r}}$ of $\mathrm{LDL}$. 
was plotted in relation to the $\log M_{\mathrm{r}}$ of LDL (Fig. 1).

These ratios fit reasonably in the regression curves which were calculated from the A/S ratios of the six proteins with different molecular weights. The $\mathrm{A} / \mathrm{S}$ ratios variations of all parameters were similar in the group of patients with liver cirrhosis and in the patiel ts with peritoneal carcinomatosis.

\section{Discussion}

It has been demonstrated that ascites cholesterol concentrations are markedly elevated in peritoneal carcinomatosis compared to cirrhosis and ascites cholesterol has been established as a parameter useful for the differential diagnosis of ascites (3-7). In an attempt to explain the elevated cholesterol concentration in malignant ascites, we compared the ascites to serum relation of proteins and lipoproteins in patients with cirrhosis or peritoneal carcinomatosis. Most ascitic fluid samples from cirrhotic patients were transudates with a protein concentration below $2.5 \mathrm{~g} / \mathrm{dl}$.

The analysis of six different proteins with molecular masses from $54 \mathrm{kDa}$ ( $\alpha_{1}$-antitrypsin) to $971 \mathrm{kDa}(\mathrm{IgM})$ in cerum and ascites revealed a mean $A / S$ ratio from 0.12 to 0.2 , which was significantly lower than in patients with peritoneal carcinomatosis (mean A/S ratio: 0.38-0.77). These findings demonstrate a higher selectivity in the movement of proteins from plasma to ascites in patients with cirrhosis than in patients with peritoneal carcinomatosis. Abnormalities in transcapillary-lymph hydrodynamics were a prominent feature in patients with cirrhosis and portal hypertension (17). Previous studies of the protein content of central lymph, ascitic fluid, and intra-abdominal regional lymph indicate that both the digestive tract and the liver contribute to excess visceral lymph and peritoneal fluid (18). A whole spectrum of pre-sinusoidal and post-sinusoidal obstruction may exist with cirrhosis, and the protein content of thoracic duct lymph and ascitic fluid appears to reflect the spectrum. The increased portal pressure in patients with cirrhosis is counterbalanced by serum/ascites protein gradient (19) and the protein concentration in ascites of patients with cirrhosis seems inversely related to the degree of the portal pressure (20). Since there is a close correlation between total ascitic protein and total cholesterol, one can assume that ascitic cholesterol as well as lipoprotein concentrations are inversely correlated to the height of the portal pressure (3). Increased filtration seemed to be the dominant process of the elevated microvascular protein escape in cirrhosis due to increased hepatic and extrahepatic splanchnic transcapillary protein flux (21). In our study, variations of total ascitic protein and of the A/S ratios of the different proteins in the group of patients with cirrhosis may reflect differences of portal pressure and pre- and post-sinusoidal obstruction (20). In patients with peritoneal carcinomatosis we obtained similar variations in the ascites/serum ratios of the six proteins. Increased endothelial permeability has been suggested as the major factor in the formation of ascites due to peritoneal carcinomatosis $(22,23)$. Our results support this concept since all patients with peritoneal carcinomatosis showed exudative type of ascites with low selectivity for plasma proteins of different molecular weights.

Lipoprotein (HDL and LDL) concentrations in serum, as well as in ascites, were significantly higher in patients with malignant neoplasms than in patients with cirrhosis. The differences of serum concentrations were most likely due to impaired hepatic lipoprotein synthesis in patients with cirrhosis. In serum and ascites of both groups about $85 \%$ of the total cholesterol was recovered in the HDL o. LDL fractions. These findings are in accordance with a previous study using gel filtration for fractionation of lipoproteins in malignant ascites (8). Therefore, the marked differences between total, HDL- and LDL-cholesterol in ascitic samples from patients with cirrhosis and those with peritoneal carcinomatosis could be explained only partially by differences in serum concentrations. The main reason for about 4-fold higher concentrations of cholesterol in the ascites of patients with peritoneal carcinomatosis seems to be a lower selectivity for the movement of HDI and LDL from plasma to ascites. This assumption was supported by the characteristics of the $A / S$ ratios of the six proteins and of apo- $\mathrm{A}_{1}, \mathrm{HDL}$-cholesterol, apo-B and LDL-cholesterol plotted in relation to the respective $\log M_{\mathrm{r}}$ (Fig. 1). These latter ratios fit reasonably well in the regression curves calculated from the $A / S$ ratios of six proteins with varying molecular weights.

It has been suggested that a decrease in ascites volume by diuretic treatment is associated with increased protein concentrations (24). In our study a similar ratio of patients in both groups received diuretic treatment. A considerable decrease in ascites volume by diuretics is usually seen in cirrhotic patients, while patients with ascites and peritoneal carcinomatosis remain refractory to diuretics in most cases. Thus, a possible increase of ascitic fluid protein following diuretics would primarily affect the patients with cirrhosis and the actual difference in ascitic fluid proteins would be even greater. It has been suggested in a case report by Loiudice et al. that in cirrhotic patients with long-standing ascites there seemed to be a tendency for cholesterol concentrations to increase (25). The history of ascites in our patients varied from a few weeks to 2 years and tended to be longer in cirrhotic patients than in 
those with peritoneal carcinomatosis. In particular, patients with long-standing ascites were generally cirrhotics.

Furthermore, in serial studies of some ascitic patients, protein or lipid concentrations in the ascites did not increase during follow-up. Therefore, our results do not support the observation (25) that ascitic cholesterol concentration is correlated to the length of history of ascites.

Lymphatic congestion or blockage might have affected protein or lipoprotein concentrations in our patients with peritoneal carcinomatosis. However, liver metastasis had been excluded in these patients by abdominal ultrasound and no patient with chylous ascites was included in the study. Therefore, it seems unlikely that involvement of lymphatics might have affected our results.

In conclusion, our results show that an increased movement of the plasma lipoproteins HDL and LDL into as-

\section{References}

1 Rovelstad RA, Bartholomew LG, Cain JC, McKenzie BF, Soul EH. The value of examination of ascitic fluid and blood for lipids and for proteins by electrophoresis. Gastroenterology 1958; 34: 436-50.

2 Polak M, de Costa ACT, Bitelmann B, et al. Diagnostic value of the biochemical profile (protein, cholesterol, glucose, mucoprotein, amylase) of ascitic fluid. Rev Hosp Clin Fac Med S Paulo 1978; 33: 186-99.

3 Jüngst D, Gerbes AL, Martin R, Paumgartner G. Value of ascitic lipids in the differentiation between cirrhotic and malignant ascites. Hepatology 1986; 6: 239-243.

4 Mortensen PB, Kristensen SD, Bloch A, Jacobsen BA, Rasmussen SN. Diagnostic value of ascitic fluid cholesterol levels in the prediction of malignancy. Scand J Gastroenterol 1988; 23: 1085-8.

5 Prieto M, Gomez-Lechon MJ, Hoyos M, Castell JV, Carasco D, Berenguer J. Diagnosis of malignant ascites (comparison of asciiic fibronectin, choiesterol, and serum-ascites albumin differences). Dig Dis Sci 1988; 33: 833-8.

6 Gerbes A, Xie Y, Metzger J, Jüngst D. Ascitic fluid concentrations of fibronectin and cholesterol: comparison of differential diagnostic value with the conventional protein determination. Liver 1990; 10: 152-7.

7 Romette J, di Constanzo-Dufetel J. Marqueurs biochimiqtias de l'origine tumorale d'une ascite. Path Biol 1989; 37: 720-4.

8 Caselmann WH, Jüngst D. Isolation and chisiacterization of a cellular protein-lipid complex from ascites fitid caused by various neoplasms. Cancer Res 1986; 46: 1547-52.

9 Suzuki N, Kawashima S, Deguchi K, Ueta N. Low dersity lipoproteins from human ascites plasma. J Biochem 1980; 87: 1253-6.

10 Röschlau P, Bernt E, Gruber W. Enzymatische Bestimmung des Gesamt-Cholesterins im Serum. Z Klin Chem Biochem 1974; 12 : 403-7.

11 Lopes-Virella MF, Stone P, Ellis S, Colwell JA. Cholesterol determination in high-density lipoproteins separated by three different methods. Clin Chem 1977; $23: 882-4$.

12 Kerscher L, Schiefer S, Draeger B, Maier J, Ziegenhorn J. Pre- cites of patients with peritoneal carcinomatosis compared to patients with cirrhosis is the main reason for the marked differences of total ascitic cholesterol in these groups of patients. These findings elucidate the pathophysiology of elevated ascites cholesterol in malignant ascites.

\section{Acknowledgements}

The author would like to thank Peter Weisweiler, M.D., for his help in the apoprotein determination, and Benedikta Zündt for the preparation of the manuscript. Yining Xie, M.D. was funded by the Hanns-Seidl-Stiftung, Munich.

cipitation methods for the determination of LDL-cholesterol. Clin Biochem 1985; 18: 118-25.

13 Weichselbaum TE. An accurate and rapid method for the determination of protein in small amounts of blood serum and plasma. Am J Clin Pathol 1946; 16: 40-9.

14 Conrad A, Schürmann J, Kreutz FH, Sieber A. Ausarbeitung einer Methode zur quantitativen Proteinbestimmung mit Hilfe eines Laser-Nephelometers im Routinelabor. J Clin Chem Clin Biochem 1978; 16: 299-305.

15 Weisweiler P, Schwandt P. Determination of human apolipoproteins A-I, B, and E by laser nephelometry. J Clin Chem Clin Biochem 1984; 22 : 113-8.

16 Henderson JM, Stein S, Kutner M, Wiles MB, Ansley JD, Rudmann $D$. Analysis of twenty-three plasma proteins in ascites. Ann Surg 1980; 192: 738-42.

17 Witte CL, Witte MH, Dumont AE. Lymph imbalance in the genesis and perpetuation of the ascites syndrome in hepatic cirrhosis. Gastroenterology 1980; 78: 1059-68.

18 Lifshitz S. Ascites pathophysiology and control measures. Int J Rad Oncol Biol Phys 1982; 8: 1423-6.

19 Pare P, Talbot J, Hoefs JC. Serum-ascites albumin concentration gradient: a physiologic approach to the differential diagnosis of ascites. Gastroenterology 1983; 85: 240 4.

20 Hoefs JC. Serum protein concentration and portal pressure determine the ascitic protein concentration in patients with chronic liver disease. J Lab Clin Med 1983; 102: 260 -73.

21 Henriksen JH, Parving H-H, Lassen NA, Winkler K. Filtration as the main mechanism of increased protein extravasation in liver cirrhosis. Scand J Clin Lab Invest 1980; 40: 121-8.

22 Hirabayashi K, Graham J. Genesis of ascites in ovarian cancer. Am J Obstet Gynecol 1970; 106: 492-7.

23 Garrison RN, Kaelin LD, Heuser LS, Galloway MA. Malignant ascites. Clinical and experimental observations. Ann Surg 1986; 203: 644-51.

24 Hoefs IC. Increase in ascites white blood cell and protein concentrations during diuresis in patients with chronic liver disease. Hepatology 1981; 1: 249-54.

25 Loiudice T, Mishkin FR, Piziak V, Barnaby H. Cholesterol ascites in alcoholic cirrhosis. Am J Gastroenterol 1979; 72: 428-30. 